\title{
ASSOCIATION OF UMBILICAL CORD LENGTH WITH MODE OF DELIVERY
}

\section{Tanveer Shafqat ${ }^{\prime \otimes}$, Shandana Bawar', Rehana Rahim'}

\section{ABSTRACT}

OBJECTIVE: To find out the average length of umbilical cord, variation in umbilical cord length in our antenatal women and to see the the association of umbilical cord length with mode of delivery.

METHODS: This cross-sectional study was carried out at Lady Reading Hospital, Peshawar Pakistan, from Jan 2018 to Dec 2018. Using non-probability convenience sampling technique, 3300 pregnant women with singleton fetus between 37-42 weeks of gestation were included in the study. Umbilical cord length was measured by standard measuring tape. Umbilical cord length was divided into three groups and its association with mode of delivery was noted in each group.

RESULTS: Umbilical cord length in our study varied from $31-100 \mathrm{~cm}$. The mean umbilical cord length was $56 \pm 9.01 \mathrm{~cm}$ among 3,300 participants. Short umbilical cord length $(\geq 40 \mathrm{~cm})$ was found in $62(1.8 \%)$ cases, out of which $36(58.06 \%)$ normal vaginal delivery (NVD) while 21 (33.87\%) had Caesarean section (CS). Normal umbilical cord length $(4 \mathrm{I}-70 \mathrm{~cm})$ was found in $\mathrm{n}=3,079(93 \%)$ participants, out of which 2, 188 (7I.06\%) had NVD while CS rate was $17.1 \%$ $(n=526 / 3079)$. Long umbilical cord $(>70 \mathrm{~cm})$ was found in $159(4.8 \%)$ cases, where $96(60.4 \%)$ had NVD and 31 (19.5\%) had CS. Nuchal cords were more common in long umbilical cord group ( $n=136 / 159 ; 85.53 \%)$ as compared to normal $(n=371 / 3079 ; 12.04 \%)$ \& short cord length $(n=3 / 62 ; 4.83 \%)$.

CONCLUSION: Both long and short umbilical cords are associated with higher rate of operative vaginal delivery and caesarean section. Nuchal cords were more in long umbilical cord group.

KEY WORDS: Caesarean Section (MeSH); Nuchal Cord (MesH); Operative vaginal delivery $(\mathrm{Non}-\mathrm{MeSH})$; Umbilical cord length (Non-MeSH).

THIS ARTICLE MAY BE CITED AS: Shafqat T, Bawar S, Rahim R. Association of umbilical cord length with mode of delivery. Khyber Med Univ J 2020; I 2(4): 284-7. DOI: I0.35845/kmuj.2020.20I36.

\section{INTRODUCTION}

$\mathrm{T}$ he umbilical cord provides main connection between fetus and placenta. It is covered by amnion and contains one large vein and two small arteries, supported in Wharton's jelly. Umbilical cord is the main source of transfer of vital nutrients to the fetus through oxygenated blood via umbilical vein and carries deoxygenated blood back from fetus via umbilical arteries to placenta.'

The umbilical cord begins to form around 5 weeks after conception. It becomes progressively longer until 28 weeks of pregnancy, reaching an average length of 50 to $60 \mathrm{~cm}$. As the cord gets longer it coils around itself to become more tortous. ${ }^{2}$

The umbilical cord length, its position, insertion into placenta and its anomalies are subject to a wide variation and untoward gestational events. The cord insertion and length in the amniotic cavity remain unrecognized till the birth of the baby. ${ }^{3}$

Umbilical cord is found to be a marker of intautetine complication to the fetus, like increased susceptibility to congenital malformations, cord
I. Gynae "B" Unit Medical Teaching Institute Lady Reading Hospital (MTI-LRH), Peshawar, Pakistan.

Email ${ }^{凶}$ : doctortanveershafqat@yahoo.com Contact \# : +92-334-9192908

Date Submitted: February 25, 2020

Date Revised: December 03, 2020

Date Accepted: December 07, 2020

accidents and mechanical bands around fetal limbs. Cord length may vary according to the length and weight, but had no relationship with the gender of the baby.

Umbilical cord can grow from 40-300 $\mathrm{cm}$ long, allowing the baby to have enough cord to move safely without causing damage to the fetus, cord and placenta. At birth the mature cord is about $50-60 \mathrm{~cm}$ in length and $12 \mathrm{~mm}$ in diameter. A long cord is defined as $>70$ $\mathrm{cm}$ and short cord as $<40 \mathrm{~cm}$. Short umbilical cord is uncommon and found in only $6 \%$ of pregnancies. ${ }^{4}$

Short umbilical cord may be associated with adverse maternal outcomes such as failure to descend of presenting part, prolonged labour, placental abruption, operative vaginal delivery and cesarean section. Excessively long umbilical cords are associated with cord prolapse, nuchal cords, true knots, entanglement around the fetus and delivery complication due to fetal distress. ${ }^{5,6}$

Antenatal diagnosis of umbilical cord abnormalities is possible by Colour Doppler ultrasound. Three Dimensional Ultrasoundis also used to see cord around the neck and cord entanglement. Coluor Doppler ultrasound is more sensitive and specific in diagnosing nuchal cords. Extra coiling of cord on Colour Doppler can predict long cord. ${ }^{7}$

There is no local data on cord lenth in our local population, so we planned this study to find out the average cord length, variation in cord length in our 
TABLE I: FREQUENCY DISTRIBUTION OF CORD LENGTH AMONG STUDY PARTICIPANTS $(\mathrm{N}=3,300)$

\begin{tabular}{|l|c|c|c|}
\hline \multicolumn{2}{|c|}{ Cord length $(\mathrm{cm})$} & Frequency & Percentage \\
\hline Short cord $(\mathrm{n}=62)$ & $31-40$ & 62 & 1.9 \\
\hline \multirow{4}{*}{$\begin{array}{l}\text { Normal length } \\
(\mathrm{n}=3079)\end{array}$} & $4 I-50$ & 739 & 22.39 \\
\cline { 2 - 4 } & $5 I-60$ & 1764 & 53.45 \\
\cline { 2 - 4 } & $6 I-70$ & 576 & 17.45 \\
\cline { 2 - 4 } & $71-80$ & 125 & 3.78 \\
\hline \multirow{2}{*}{$\begin{array}{l}\text { Long cord } \\
(\mathrm{n}=159)\end{array}$} & $81-90$ & 26 & 0.78 \\
\cline { 2 - 4 } & $91-100$ & 08 & 0.24 \\
\hline
\end{tabular}

pregnant women and to see the association of cord length with mode of delivery.

\section{METHODS}

This cross-sectional study was carried out in Gynae B unit Lady Reading Hospital, Peshawar Pakistan, from Jan 2018 to Dec 2018, after obtaining ethical approval from Hospital Ethical committee. Using non-probability Convenience sampling, 3300 pregnant women were included in this study. All pregnant women with singleton fetus between 37-42 weeks of gestation who delivered in obstetrics "B" unit of MTI, LRH Peshawar were included in the study. All of them presented in spontaneous labour. Women with fetal demise, anomalous babies, induced labour, previous caesarean section, and having medical disorder like hypertension or diabetes were excluded from this study. Both primigravida and multigravida women were included.

The progress of labour was plotted on Partogram, fetal heart rate monitored by intermittent auscultation and fetal Doppler. Electronic fetal heart rate monitoring by Cardiotocograoh (CTG) was done when required. Fetal blood sampling was not done due to non availability of this facility.

Umbilical cord was examined after delivery whether vaginal or operative for presence of loops around neck, trunk or shoulders. Nuchal cords with number of loops were counted. Knots in the cord (true or false), cord insertion in placenta whether central, eccentric, marginal or velamentous were also noted.
After the delivery of fetus cord was clamped at two places and cut in between. Length was measured from cut end to fetal umbilicus and from other end to insertion into placenta. These two measurements were added to know total length of umbilical cord. Cord length was measured with a flexible tape in centimeters $(\mathrm{cm})$. Cord length of less than $40 \mathrm{~cm}$ was considered short length, $41-70 \mathrm{~cm}$ was taken as normal length and more than $70 \mathrm{~cm}$ was considered long cord Maternal outcome was noted in terms of mode of delivery whether it was vaginal, operative vaginal or cesarean section. Statistical analysis was done using SPSS version 22. Chi square test was used to find out $p$ value

\section{RESULTS}

In this study, mean age of 3,300 women was $29.32 \pm 3.26$ years. Parity ranged between 1-6. Maximum cases seen were $n=3,079$ (93.29\%) in the group of cord length between $4 \mathrm{I}-70 \mathrm{~cm}$, while long cord $70-100 \mathrm{~cm}$ was found in 159 (4.8I\%) cases followed by short cord in $62(1.9 \%)$ cases. (Table I) Lower 5 th percentile $(<40 \mathrm{~cm})$ was considered as short cord and upper 5 th percentile $(>70 \mathrm{~cm})$ was considered as long cord.

Caesarean section cases were highest in short cord group ( $\mathrm{n}=2 \mathrm{1} / 62 ; 33.87 \%$ ). Rate of normal vaginal delivery were found highest in patients with normal cord length $(n=2188 / 3,079 ; 71.06 \%)$. No Breech vaginal delivery was seen in short cord and length above $80 \mathrm{~cm}$ (Table II).

Nuchal cords were more common in long umbilical cord group $(n=136 / 159$; $85.53 \%)$ as compared to normal $(n=371 / 3079 ; 12.04 \%) \&$ short cord length $(n=3 / 62 ; 4.83 \%)$ [Table III]. Placental insertion of cord was central in 2,108 (63.87\%), marginal in 960 (29.09), eccentric in $228(6.09 \%)$ while velamentous in only $4(0.12 \%)$ patients.

\section{DISCUSSION}

Our study included 3300 women who came in spontaneous labour and had delivery in our labour suit. Mean age of our women was $29.32 \pm 3.26$ years and parity ranged between I-6. We included 3300 women (cocecutive convevient sampling) in our study as we had no data available in Pakistan regarding measurement of average cord length in our pregnant women. Two studies from India included one thousand and 500 women to see the association of umbilical cord length with perinatal outcome and mode of delivery. ${ }^{14,16}$

Mean umbilical cord length in the present study was $56 \pm 9.01 \mathrm{~cm}$. Maximum numbers of cases were found in range of $41-70 \mathrm{~cm}(93.29 \%)$ and this was labeled as normal cord length group. Same observations were found in study by Olaya. ${ }^{8}$ Short umbilical cord was seen in $62(1.9 \%)$ and long cord in 159 (4.8I\%) cases in our study. Nuchal cord was found in 108 (67.92), 5 cases with single loop, and total number of $136(85.53 \%)$ cases. Three loops of cord were present in 8 (12.57\%) cases in long cord group. Higher percentage of nuchal cord was seen in long cord group. These results are comparable to a study by Sanad ZF, et al. ${ }^{9}$

The incidence of operative intervention increases at extremes of length i.e. both short and long cord. In short cord risk of fetal distress and labour abnormalities in terms of failure to descend of presenting part increases which leads to increased incidence of instrumental deliveries and caesarean section. ${ }^{10,11}$ In our study instrumental deliveries were $8.6 \%$ and caesarean sections were $33.87 \%$ in short cord compared to normal length which was $8.3 \%$ and $17.00 \%$. These results are comparable to study by Dolgun ZN, et al. and Krakowik P, et al. ${ }^{12,13}$

Long cord group had more than $70 \%$ cesarean section due to fetal distress 
TABLE II: ASSOCIATION OF UMBILICAL CORD LENGTH WITH MODE OF DELIVERY

\begin{tabular}{|c|c|c|c|c|c|c|c|}
\hline \multicolumn{2}{|c|}{ Cord length $(n=3,300)$} & \multicolumn{5}{|c|}{ Mode of delivery } & \multirow[t]{2}{*}{ P. Value } \\
\hline $\begin{array}{l}\text { Type of } \\
\text { Umbilical } \\
\text { cord }\end{array}$ & $\begin{array}{l}\text { Length of } \\
\text { cord }\end{array}$ & $\begin{array}{l}\text { NVD } \\
\text { n (\%) }\end{array}$ & $\begin{array}{l}\text { VBAC } \\
\text { n (\%) }\end{array}$ & $\begin{array}{c}\text { Breech } \\
\text { n (\%) }\end{array}$ & $\begin{array}{c}\text { Instrumental } \\
\text { delivery } \\
\text { n (\%) }\end{array}$ & $\begin{array}{c}\text { Cesarean } \\
\text { section } \\
\text { n (\%) }\end{array}$ & \\
\hline $\begin{array}{l}\text { Short cord } \\
(n=62)\end{array}$ & $31-40 \mathrm{~cm}$ & $36(58.06 \%)$ & 0 & 0 & $05(8.06 \%)$ & $2 \mathrm{I}(33.87 \%)$ & $P<0.002$ \\
\hline \multirow{3}{*}{$\begin{array}{l}\text { Normal cord } \\
(n=3,079)\end{array}$} & $\begin{array}{c}4 I-50 \mathrm{~cm} \\
\mathrm{n}=739\end{array}$ & $608(82.27 \%)$ & $19(2.57 \%)$ & II (1.48\%) & $57(7.71 \%)$ & $127(17.18 \%)$ & \multirow{3}{*}{$P<0.025$} \\
\hline & $\begin{array}{c}5 I-60 \mathrm{~cm} \\
\mathrm{n}=1764\end{array}$ & II5I (65.24\%) & $19(1.07 \%)$ & $21(1.19 \%)$ & I I 8 (6.68\%) & 306 (I7.34\%) & \\
\hline & $\begin{array}{c}61-70 \mathrm{~cm} \\
\mathrm{n}=576\end{array}$ & $429(74.47 \%)$ & $17(2.95 \%)$ & $20(3.47 \%)$ & $83(14.40 \%)$ & $93(16.14 \%)$ & \\
\hline \multirow{3}{*}{$\begin{array}{l}\text { Long cord } \\
(n=159)\end{array}$} & $\begin{array}{c}7 I-80 \mathrm{~cm} \\
\mathrm{n}=125\end{array}$ & $90(56.6 \%)$ & $06(3.77 \%)$ & $06(3.77 \%)$ & $15(9.4 \%)$ & $17(10.60 \%)$ & \multirow{3}{*}{$P<0.002$} \\
\hline & $\begin{array}{c}8 I-90 \mathrm{~cm} \\
\mathrm{n}=26\end{array}$ & $06(3.77 \%)$ & 0 & 0 & $02(1.25 \%)$ & $9(5.66 \%)$ & \\
\hline & $\begin{array}{c}91-100 \mathrm{~cm} \\
\mathrm{n}=08\end{array}$ & 0 & $02(1.25 \%)$ & 0 & OI (0.62\%) & $05(3.14 \%)$ & \\
\hline
\end{tabular}

TABLE III: FREQUENCY DISTRIBUTION OF NUCHAL CORDS AMONG VARIOUS UMBLICAL CORD GROUPS

\begin{tabular}{|c|c|c|c|c|c|c|}
\hline \multirow{3}{*}{$\begin{array}{l}\text { NO OF } \\
\text { LOOPS }\end{array}$} & \multicolumn{6}{|c|}{ CORD LENGTH } \\
\hline & \multicolumn{2}{|c|}{$\begin{array}{l}\text { Short } \\
<40 \mathrm{~cm} \\
(n=62)\end{array}$} & \multicolumn{2}{|c|}{$\begin{array}{l}\text { Normal } \\
41-70 \mathrm{~cm} \\
(n=3079)\end{array}$} & \multicolumn{2}{|c|}{$\begin{array}{l}\text { Long Cord } \\
>70 \mathrm{~cm} \\
(n=159)\end{array}$} \\
\hline & $\mathbf{n}$ & \%age & $\mathbf{n}$ & \%age & n & \%age \\
\hline One & 3 & 4.83 & 270 & 8.76 & 108 & 67.92 \\
\hline Two & 0 & 0.0 & 76 & 2.46 & 20 & 12.57 \\
\hline Three & 0 & 0.0 & 25 & 0.81 & 08 & 5.03 \\
\hline TOTAL & 3 & 4.83 & 371 & 12.04 & 136 & 85.53 \\
\hline
\end{tabular}

which was secondary to nuchal cords, cord prolapse, and fetal heart rate abnormalities. Fetal distress was diagnosed on the basis of pathological CTG findings. This should be confirmed by fetal blood sampling but we don't have this facilityin our Hospital. Instrumental deliveries were $11.3 \%$ and caesarean sections were $19.49 \%$ in this group. These results are comparable to study by Nandini B, et al. $^{14}$

Our result show higher rates of caesarean delivery in both long and short cord lengths compared to study by La Monica GE, et al. ${ }^{15}$ Same risks of operative interference are given for both long and short cord in a study by Shiva Kumar HC, et al. as observed in our study. ${ }^{16}$ In a study by Yadav BB, et al. caesarean section rate was significantly high in long cord with two loops of nuchal cord $(p<0.001) .{ }^{17}$ Short cords were associated with failed progress of labour and increased operative delivery. ${ }^{18}$ Poor perinatal outcome was seen in cases of short and excessively long cords. ${ }^{19,20}$

\section{CONCLUSION}

Umbilical cord length is associated with mode of delivery. Short and long umbilical cords are associated with increased incidence of operative vaginal delivery and caesarean section. Nuchal cords were more common in long umbilical cord group. Unfortunately we don't have any studies or data related to length of umbilical cord in our pregnant women. We need to perform other studies in which Colour Doppler ultrasound findings (in Antenatal women) of nuchal cord and excessive coiling of umbilical cord is confirmed at the time of delivery.

\section{REFERENCES}

I. Benirschke K. The Umbilical Cord. Neo Reviews 2004;5(4):34

2. Cruikshank DW, ScoottJR. Breech, other malpresentation, and umbilical cord complications. Danforth's Obstetrics and Gynaecology 9th edition. Philadelphia, Lippincott Williams and Wikins, 2003, page 38I-95

3. Carlo WA, Ambalavanan N. The umbilicus. In Klieginan RM, Nelson textbook of pediatrics $20^{\text {th }}$ Edition, 2016;890-91

4. Ranga MKSS, Mallika V. Morphplogical variations of Umbilical cord in Human Placenta. Int J Anat Res July 2019; 7(3): 78689. DOI: 10.16965/ijar.2019.226.

5. Sharma S, Soliriya V. Study of length of umbilical cord at term and its correlation with fetal outcome: a study of 500 deliveries. J South Asian Feder Obst Gynae 2016;8(3):207II. DOI: 10.5005/jp-journals10006-1419.

6. Algreisi F, Brown R, Shrim A, Albasri SF, Shamarani H, AlZoubiadi A. Effect of long and short umbilical cord on perinatal outcome. Int J Reprod Contracept Obstet Gynecol 
20I6;5(I2):4228-3I. DOI: 10. 18203/2320-1770.ijrcog20I64042.

7. Hanaoka U, Yanagihara M, Tanaka $\mathrm{H}$, Hata T. Comparision of threedimensional, two dimensional and colour Doppler ultrasoundin predicting presence of nuchal cord at birth. Ultrasound Obstet Gynaecol 2016;19(5):47I-4. DOI: I 0.1046/j.1469-0705.2002. 00670.x.

8. Olaya-C M, Bernal JE. Clinical association to abnormal umbilical cord length in Latin American newborns. J Neonatol Perinatal Med 20I5;8(3):25I-6. DOI: 10.3233/NPM-I59|5056.

9. Sanad ZF, Sayyed TM, Ammar HA, El-Kherbawy MF. Effects of Umbilical cord entanglement on pregnancy outcome. Monoufia Med J 2019.32;(2):448-52. DOI: 10. 4I03/mmj.mmj_672_I7.

10. Yamamoto Y, Aoki S, Oba MS, Seiki K, Hirahara F. Relationship between Short Umbilical Cord length and adverse Pregnancy outcome. Fetal Pediatr Pathol 2016;35(2):8I-7. DOI: $10.3109 / 15513815.2015$. II 22 I 26.
II. Linde LE, Rasmussen S, Kessler J, Ebbing C. Extremes of umbilical cord lengths, cord knot and entaglement: Risk factors and risk of adverse outcomes, a population based study. PLoS One 2018;13 (3):e0 I948|4. DOI: 10.137/journal. phone.01948I4.

12. Dolgun ZN, Inan C, Altintas AS, Okten SB, Karadag CS, Sayin NC. Is there $A$ relationship between route of delivery, perinatal charateristics, and neonatal outcome in preterm birth? Niger J Clin Pract 2018; 2I(3):3I2-17. DOI: 10.4I03/njcp. njcp_333_16.

13. Krakowiak P, Smith EN, de Bruyn G, Lydon-Rochelle MT. Risk factors and out comes with a short umbilical cord. Obstet Gynecol 2004;103 (I): 119-27.

14. Nandini B, Deepali J, BalGopal B, Shaheen A, Jyothi D. Relationship between umbilical cord length and maternal and fetal outcome. Ind J Res July 2015;4(7): I I4-7.

15. LaMonica GE, Wilson ML, Fullilove AM, Rayburn WE. Minimum cord length that allows spontaneous vaginal delivery. J Reprod Med 2008 March;55(3):217-9.
16. Shiva Kumar HC, Tharihalli CT, Chandrashekhar K, Gaddi SF. Study of umbilical cord and fetal outcome: a study of 1000 deliveries. Int J Reprod Contracept Obstet Gynecol 2017 Sep; 6(9):3770-5. DOI: $10.18203 / 2320-177$. ijrcog20I 73622.

17. Yadav BB, Kurdukar DV, Darade RV, Mahadar NA. Correlation of umbilical cord length with fetal and maternal outcome. J Evol Med and Dent Sci 20 I 3 Jan 28;(2):4 I 2- I 7.

18. Joshi K, Saxena R, Bhat M, LomordY, Verma K. Incidence of cord around the neck and its effects on labour and neonatal outcome. Adv Human Biol 2017 Jan;7(I): 15-8. DOI: 10.4I03/232I-8568.199535.

19. Khadim EJ, Ali YNM, Sher SS, Fawzi HA. The Length of Umbilical cord and perinatal outcome. Ind J Public Health Res Dev 2019;10(5):576-80. DOI: $10.5958 / 0976-5506.2019$. 01068.4 .

20. Soliriya V, Goyal M, Kachhawaha CP. Perinatal mortality and umbilical cord parameters. Is there any association? J Preg Child Health Jul 2017;4(4): I0-3. DOI: 10.4I72/ 2376- $127 X .1000340$

\section{AUTHORS' CONTRIBUTIONS}

Following authors have made substantial contributions to the manuscript as under

TS: Acquisition of data, data analysis, drafting the manuscript, approval of final version to be published

SB: Acquisition of data, drafting the manuscript, approval of final version to be published

RR: Conception and study design, Analysis and interpretation of data, drafting the manuscript, approval of the final version to be published

Authors agree to be accountable for all aspects of the work in ensuring that questions related to the accuracy or integrity of any part of the work are appropriately investigated and resolved.

CONFLICT OF INTEREST

Authors declared no conflict of interest GRANT SUPPORT AND FINANCIAL DISCLOSURE NIL

\section{DATA SHARING STATEMENT}

The data that support the findings of this study are available from the corresponding author upon reasonable request.
KMUJ web address: www.kmuj.kmu.edu.pk

Email address: kmuj@kmu.edu.pk 